\title{
Trust Aspect Based on Sekala Niskala's Accountability and Transparency Practices Traditional Village Fund Management
}

\author{
Kadek Sufridayani ${ }^{1}$ I Gusti Bagus Palguna ${ }^{1 *}$, I Nyoman Putra Karnata ${ }^{1}$ Ni \\ Nyoman Sriyani ${ }^{1}$ Komang Bintang Rosita Dewi ${ }^{1}$ Shefira Marina Putri ${ }^{1}$
}

\author{
${ }^{1}$ Department of Economic and Accounting, Universitas Pendidikan Ganesha, Singaraja, Indonesia \\ *Corresponding author. Email: bagus.palguna@undiksha.ac.id
}

\begin{abstract}
This study discusses how aspects of a scale-based trust in the practice of accountability and transparency of customary village fund management with the aim of knowing the embodiment of trust aspects in the management accountability of funds in the Penglatan Traditional Village in Buleleng, and to find out the embodiment of trust aspects in the transparency of managing funds in the Penglatan Traditional Village, Buleleng Village. Data collection methods and instruments used in this determination were data collection methods consisting of Observation Methods, Interview Methods, Documentation Methods, Literature Studies, while for data analysis techniques used in this study were triangulation / data validity. The results showed that the aspect of trust is based on a scale scale in the practice of accountability and transparency in managing the traditional village funds of Penglatan, which is already based on the principles of transparency and the principles of accountability for continuous improvement while still adjusting the situation and conditions as well as developments in the prevailing laws and regulations. is Data Reduction. Presentation of data. Conclusion drawing and with the need to be done.
\end{abstract}

Keywords: Trust, Transparency, Accountability, Fund Management

\section{INTRODUCTION}

Balinese people, like indigenous peoples throughout Indonesia, have a social framework that includes an indigenous society. Traditional Balinese settlements consist of villages or Pakraman villages, which are frequently referred to as traditional villages. This Pakraman village is a social and traditional organization that demonstrates its characteristics through territorial and environmental areas with clear boundaries, its members or krama based on special circumstances, Khayangan Tiga or other holy places that are used in religious ceremonies, and autonomy both outside and inside [1] The interaction between the components inside the Pakraman village is governed by customary regulations known as awig-awig, which can be expressed in writing or unwritten as agreed upon by all indigenous community members. Awig-awig is formulated cooperatively through paruman activities carried out by krama from the Pakraman village or the village council that hosts the gathering. Pakraman village's social life on the Indonesian island of Bali is built on the notion of Tri Hita Karana. According to Pitana (1994) [1] "in order to realize the teachings of
Tri Hita Karana, namely Parahyangan, Pawongan, and Palemahan, Pakraman village also owns the right to autonomy, specifically autonomy in socioeconomic matters, which confers authority over relations between members of their community associations and over their Pakraman village assets." These assets may be classified as "movable property" or "immovable property."

Pakraman village, as a traditional institution, must adapt to changing times. According to [1] there are two polarizing views in development studies. First, there are the ideas of revolutionaries who believe that conventional institutions must be abolished since they impede development. Second, the opinion of reformists who believe that many traditional institutions or local community groupings with a cultural foundation do not impede progress but rather contribute to it. In this situation, reformers believe that Pakraman village possesses social capital in the form of norms and traditions that might serve as a foundation or guide for supporting the community's financial management. The cultural foundation in the form of social capital in the form of the Tri Hita Karana ideology, as well as the customs 
and traditions of the Pakraman village, can be used to aid in the comprehension of all aspects of the Pakraman village's financial management process. Even Nugroho and Dahuri (2004) assert in Atmadja (2006) that development will be more successful if it incorporates natural resource capital (SDA), human assistance capital (HAC), human resource capital (HR), and social capital. This relates to the way the Pakraman village community manages its funds in accordance with its customs and traditions.

There is currently a paradigm change occurring in the management of village finances. Prior to the enactment of Law No. 6 of 2014 on Villages, the village was viewed solely as an object of top-down development. Village interests and requirements are frequently ignored, as the development flow or process in the village is frequently driven by political content generated by interested parties. The village's situation has shifted. In the current state of affairs, traditional villages are granted the broadest authority possible to regulate all demands that become genuine and authentic, one of which is the management of funds collected from local government and other sources of revenue. With an increasingly autonomous traditional village, the Pakraman village faces even greater obstacles and threats. In the future, opportunities for abnormalities, particularly in financial problems, are unavoidable.

In addition to utilizing transparency and accountability in financial management, traditional villages leverage social capital, which is defined as the relationships and norms that embody the quality of social ties across a broad spectrum of social life, namely strengthening social relations that contribute to community unity. Social capital is transmitted through cultural processes such as religion and historical/traditional customs [2]. The primary component of social capital that is critical is trust, or what is referred to as believe. Additionally, trust can be viewed as an essential prerequisite for the construction and development of a society's social capital's strength or weakness. Indeed, individuals possess the capacity for enormous confidence (high trust) or a broad (long) spectrum of views, implying that they possess the capacity for significant potential social capital. On the other side, individuals who lack trust or who hold a narrow range of views may have low potential social capital. Affirmed this view, stating that trust is the assumption that everyone in society can be depended upon because they are honest with one another.

According to this study, including social capital in financial reporting increases openness and accountability for all village leaders, as well as traditional village communities. If it cannot be separated from the truth that the manners of the traditional village exist between the community and the traditional village apparatus, then each of them must adhere to the rules that apply in the traditional village. Thus, regardless of the form of fraud perpetrated, the culprit can face punishment under custom.

Due to the fact that this traditional village may practice both modernization and traditional culture, which captures the attention the reviewers' curiosity, the research place was chosen as the "Penglatan Traditional Village." The Penglatan Traditional Village was chosen because it is one of the traditional villages that receives financing from the province government to implement socio-religious activities within the traditional village context. Naturally, traditional village financial management is critical (according to Mr. Wayan Susila, Penglatan Village Customary Officer, in an informal interview on 28 June 2020), not only as a source of funds for indigenous peoples' activities, but also as a form of moral and social responsibility to the indigenous community.

Penglatan Traditional Village is, of course, identical to other traditional villages that receive Traditional Village Budget Allocations for development implementation. The budget allocation for Dusun Adat is transferred directly to the Dusun Adat account, and no Special Financial Assistance (BKK) is required in its mechanism. Special Financial Assistance for traditional communities was previously administered through the village's official office, making payment more cumbersome (Ms. 2020 at http://www.balipost.com). Additionally, an intriguing characteristic from the Penglatan Traditional Village is that the customary Bendesa (chairman) is elected through a paruman (meeting) or a direct election held at the Banjar Hall. Additionally, only individuals who are eligible to designate themselves as Penglatan Indigenous Village Heads from the father of "Werdhi Ayu" may do so. Each candidate for the elected Bendesa (chairman) and Prajuru (manager) positions is required to do mepiuning (prayer) at Pura Bukit. This is to take an oath on a periodic and niskala basis that all work or tasks performed for the community must be completed with sincerity, fairness, honesty, and transparency, particularly in financial management, so that if there is a problem / fraudulent act in the community or in the management of funds village, those responsible will face adat and karma phala sanctions. The belief in the law of karma phala (niskala) has a significant influence on what they do in the community and traditional villages, because the village community has entrusted the traditional 
prajuru with the responsibility of managing village funds prudently, and if that trust is betrayed, they must accept all the consequences (custom or customary law).

The Balinese believe in the terms sekala and niskala, which are profoundly ingrained in their daily lives, where the terms refer to the visible and invisible. It is considered to provide direction, enabling people to live a balanced existence. The terms sekala and niskala refer to the worlds of reality and unreality, and when used in conjunction with the financial responsibility report / village fund management report, they have a significant impact on the village community's trust value. For instance, if village fund reports lack openness and accountability, the village official will face genuine consequences (customary sanctions) rather than real punishments (karma phala legal sanctions).

Based on the author's brief interview with the Kelian Banjar Adat of Penglatan Village (Sunday, June 28, 2020), which revealed that the Penglatan village community places a high premium on accountability for village funds. Historically, awigawig has been critical in controlling the social and religious lives of individuals living in traditional village settings. In the Penglatan Traditional Village, the resolution of all types of irregularities is mainly reliant on the traditional village awig-awig. However, the existing awig-awig solely governs deviations or problems in the social and religious realms, while money management issues remain poorly governed. Even if financial irregularities such as corruption occur, the Pakraman village will settle them through the village village approach (village manners meeting) and provide increased trust on a niskala scale.

The application of a trust-based strategy to managing traditional village finances as a means of sustaining rural government commitments in order to foster an honorable commitment and increase trust. The implication is that trust is used as a broad concept in conjunction with specific acts when enforcing legal restrictions. As previously said, one of the numerous tasks of a soldier in a traditional village, service, or service is to uphold the rights associated with customary village manners. As a result, trust-based management of traditional village finances is a must.

Another intriguing feature of Penglatan Traditional Village is that it has human resources, specifically traditional village prajuru, which have the potential to perform a variety of management functions, including financial management. However, human resources exposed to contemporary culture run the risk of developing into a very consumptive society, and consumptive conduct is one of the primary drivers of corruption or financial abuse. The Penglatan traditional village community, on the other hand, trusts and believes that the traditional village prajuru will refrain from financial abuse. This indicates that the community's high level of trust is also used as a guiding principle and specific action in implementing the management of customary village funds. With the faith of the Penglatan traditional village ways toward the traditional village prajuru in the financial statement's accountability, transparent and accountable financial reports will result.

The researcher intends to do research on "Aspects of Trust Based on a Niskala Scale in the Practice of Accountability and Transparency in the Management of Traditional Village Funds in Penglatan".

\section{METHOD}

The following research employs a qualitative methodology. Qualitative research is defined as a method based on postpositivism that is used in natural object conditions, where the researcher is the primary instrument, data sources are sampled using purposive techniques, data are collected using triangulation techniques, qualitative/inductive data analysis is used, and research findings emphasize meaning rather than generalization [3]. The Kelian Banjar Adat Penglatan, the adat prajuru (managers) who were specifically tasked with managing the Penglatan Traditional Village Fund, and the Penglatan adat village krama (community) who participated in the paruman (meeting) that discussed financial management were the subjects and objects of this study, respectively. The object of research is what matters in a study. The emphasis of attention is on the substance or material that is solved/researched from the problem employing a variety of connected theories, most notably about village financial transparency and accountability. The focus of qualitative research is on the natural environment holistically; the individual is positioned as a research tool; data analysis is conducted through induction; the process is prioritized over the results; and the researchers and research subjects agree on the research findings.

The methodology and data collection instruments utilized in this research include observation, interviews, and documentation, as well as library studies, while the technical data analysis used in this research is data reduction, presentation, drawing conclusions, and triangulation/validity of the data. Additionally, the data validity method is a 
standardization procedure used in qualitative research to ascertain the degree of trustworthiness or truthfulness of a study conclusion. To ensure the data's veracity, it is required to verify the technique (Moleong, 2000: 179). The technique is founded on four criteria: credibility, transferability, reliability, and conformability.

\section{RESULTS \& DISCUSSION}

\subsection{Penglatan Traditional Village Profile}

Penglatan Traditional Village is a government whose jurisdiction is traditional, with customary customs that embody and conserve culture. The Penglatan Traditional Village has long been critical in structuring and nurturing communal life within the traditional village and throughout the development process. As a government entity, the adat village is a really autonomous village, exercising self-governing jurisdiction within the palemahan (area) in which it continues to operate and maintains an equal position. achieved recognition in the Indonesian Republic. Each citizen of the customary village must assert the authority that has been agreed upon in order to create a peaceful and prosperous society.

According to[4] on Traditional Villages in Bali, the establishment of traditional villages in Penglatan was directed by regional legislation. The following principles guided the establishment of the Penglatan Traditional Village: kawigunan / benefit; padumpada / justice; manyama braya / kinship; gilik-saguluk / togetherness; parasparo / deliberation; salunglung sabayantaka / mutual cooperation; sarwaada/anekatwa/diversity; equality; Bali mawacara/Balines Recognizing customary villages entails recognizing agreed-upon customary institutions. In a sociological sense, the ways of traditional villages sustain the existence of traditional institutions. The traditional village's role is also seen when the tourism area is developed, when the misuse of religious symbols is monitored, and when illegal immigrants are prevented from entering the village, which is why it is also mentioned that in the traditional way, it is called the Penglatan traditional village, which is a round and intact place of life. comprises three components: kahyangan three elements (village temples), krama desa (citizen) elements, and village corals, all of which use traditional patterns and environmental tools set against a backdrop of traditional values and standards.

The Penglatan Traditional Village's mission is to develop the Kasukretan of the Penglatan Traditional Village, which entails a sense of serenity, prosperity, and happiness, as well as a sense of peace and niskala. To achieve a sekala kasukretan, the Penglatan Traditional Village has the following responsibilities: (1) regulating, administering, and protecting the implementation of Parahyangan, Pawongan, and the Palemahan Traditional Village; (2) maintaining and developing the system and application of customary law; (3) implementing the Traditional Village Sabha and Traditional Village Kerta; and (4) advancing customs, religion, arts \& culture, and traditions; (5) carry out activities in accordance with the value of Sad Kerthi; (6) operate Islamic boarding schools on a Hindu basis in order to develop Balinese citizens' identity, moral integrity, and quality; (7) maintain the security of the traditional village; (8) economic development of the traditional village; (9) safeguard the continued status of rights to the land of Padruwen Traditional Village; and (10) maintain the sanctity, preservation, and cleanliness of the traditional village; (11) conduct activities to promote and empower good manners in order to raise environmental accountability; (12) manage garbage at Wewidangan Dusun Adat; (13) conduct the five yadnya activities as taught in Hindu holy literature; (14) conduct other activities as dresta/awig-awig prescribes.

\subsection{Aspects of Trust Based on Sekala and Niskala in The Penglatan Traditional Village Fund's Accountability Practice}

Accountability for the traditional village finance management system is intended to be sought in order to foster or manage good governance. Contribution, transparency, and accountability in the implementation of development and governance are the principles or many principles of good governance [5] The level of accountability when it comes to financial management of traditional villages begins with the stages of planning, implementing, and being accountable. As stated in Bali Province Regional Regulation No. 34 of 2019 on Financial Management of Traditional Villages, financial management of the traditional Penglatan village must generally be guided by principles such as the following: (1) The management of the customary village fund (2) All activities funded by traditional village funds have been planned, implemented, and evaluated transparently and with the participation of all members of the adat village community, with the goal of enhancing and activating the functions of existing community institutions and other societal elements. (3) All operations must be accompanied by technical, administrative, and legal duties; sustainability must be maintained; and development 
should be pursued in an ongoing manner and supported by community contributions.

This corresponds to the findings of an interview with the Penglatan Traditional Village Bendesa regarding the phases involved in administering the Penglatan traditional village fund, which revealed the following:

"Prosesnya kami ambil 3 poin penting dik yaa, ada 3 tahapan yaitu tahap perencanaan, pelaksanaan dan nanti ada pertanggungjawaban. Anggaran yang diberikan dengan nominal besar harus benarbenar dikelola dengan baik terlebih lagi sekarang sudah ada aturan yang jelas."

"In the process, we take 3 important points, brother, there are 3 stages, namely the planning stage, implementation and later there will be accountability. The budget given with a large nominal must really be managed properly, especially now that there are clear rules"

He also indicated that he was prepared to manage the money for the Bali Provincial Government's traditional village training program, which has a nominal budget of hundreds of millions of rupiah for 2020 .

He also indicated that he was prepared to manage the money for the Bali Provincial Government's traditional village training program, which has a nominal budget of hundreds of millions of rupiah for 2020 .

"Persiapannya yaa harus benar-benar fix, dimulai dari perencanaan sampai laporan pertanggungjawaban. Sekarang kan ada peraturan baru yang sudah disahkan dik namanya PERGUB Bali No. 34 Tahun 2019 mengenai dikelolanya dana dusun adat. Maka dari itu, semua sudah diseragamkan sehingga kami berpedoman pada pergub ini, nama programnya untuk Desa Adat Penglatan dengan sebutan APBD Semesta Berencana." (Hasil wawancara Bendesa Adat Penglatan, tanggal ...... Nopember 2020).

"The preparation must be really fixed, starting from planning to accountability reports. Now, there is a new regulation that has been ratified, called PERGUB Bali No. 34 of 2019 regarding the management of customary hamlet funds. Therefore, everything has been uniformed so that we are guided by this gubernatorial regulation, the name of the program for the Penglatan Traditional Village is called the Semesta Planning APBD."
(Results of the Penglatan Indigenous Village Bendesa interview

While implementing the financing of Traditional Village programs, Bali is confronted with the COVID-19 outbreak, which demands immediate attention, particularly in managing and overcoming COVID-19. To combat the corona virus, the Bali Provincial Government directed that the traditional village reallocates its financial resources to combat the corona.

The Penglatan Indigenous Village Bendesa communicated the same message in an interview regarding the procedure for disbursing customary village funds, which were then allocated an additional budget to handle COVID-19.

"Nggih benar dik, jadi dulu kan Namanya Bantuan Khusus Keuangan (BKK) ini melalui desa dinas jadi lebih rumit, kalau sekarang desa adat mengajukan proposal ke provinsi nanti proses pencairannya lewat rekening desa adat yang sudah dibuatkan rekening Bank BPD. Untuk nominalnya tahun kemarin Rp 300.000.000,00 tahun 2020 sudah naik sekitar Rp 50.000.000,- jadi totalnya Rp 350.000.000,00 dikarenakan sekarang kan lagi ada musibah COVID-19. Untuk lebih jelasnya bisa adik tanyakan ke bendahara desa adat."

"You're right, so in the past, the Special Financial Assistance (BKK) through the official village became more complicated, if now the traditional village submits a proposal to the province, the disbursement process will be through the traditional village account which has been made a BPD Bank account. For last year's nominal value of $\mathrm{Rp}$. $300,000,000.00$ in 2020 it has increased by around Rp. 50,000,000, - so the total is Rp. $350,000,000.00$ because now there is a COVID-19 disaster. For more details, you can ask the treasurer of the traditional village."

In a different location dealing with the same subject, the Penglatan Traditional Village Treasurer reaffirmed the conclusions of the interview with the Penglatan Traditional Village Bendesa, stating that:

"Dana Desa Adat Penglatan awalnya pada saat pencairan tersimpan di rekening Bank BPD atas nama sendiri, lalu jika sisa kegiatan tiang simpan pada rekening di LPD Desa Adat Penglatan dalam bentuk tabungan, sehingga mekanisme pencairan nya tentu saja menarik tunai dana desa yang mana bukti penarikan ditandantangani oleh Bendesa Adat 
Penglatan atau bendahara desa adat, selain keduanya itu tidak diperbolehkan mengambil tabungan dana desa adat tsb".

“......ditahun 2019 sejumlah $R p 300.000 .000$ pada tahun 2020 sejumlah Rp 350.000.000, dana tersebut berasal dari dana yang masuk pertahun baik dari bantuan pemerintah maupun dari desa adat."

"At the time of disbursement, the Penglatan Traditional Village Fund was initially stored in the BPD Bank account in its own name, then if the remaining savings in the account at the Penglatan Traditional Village LPD were in the form of savings, then the disbursement mechanism would of course withdraw cash from the village fund where the proof of withdrawal was signed by The Penglatan Indigenous Bendesa or the treasurer of the traditional village, other than the two of them are not allowed to take the savings from the traditional village fund ".

“......in 2019 a total of IDR 300,000,000 in 2020 a total of IDR 350,000,000, these funds come from funds that come in annually both from government assistance and from traditional villages."

According to Bali Governor Regulation No. 15 of 2020, the Bali Provincial Government has been allocating funds to Traditional Villages that receive funding from the APBD since 2020. Semesta Plans for the 2020 Fiscal Year, totaling $\mathrm{Rp}$. $300,000,000.00$, have been transferred to 1,493 (one thousand four hundred and ninety-three) Dusun Adat in Bale. The monies are utilized to cover both routine and program expenses. Expenditures are frequently used to fund the Adat Village government's activities, while Program Expenditures are used to fund Adat village programs such as the Parahyangan Program, the Pawongan Program, and the Palemahan Program.

\subsection{Village Fund Planning in The Traditional Style}

It is intended that activities funded by traditional villages must truly reflect the ambition of traditional village customs. All activities funded by traditional village funds are directed at meeting the requirements of the adat village's residents and are prioritized in accordance with the regional government's guidelines for the optimal use of traditional village funds. The outcomes of the planned budgeting and program ratification with the PERDA can be utilized as recommendations for implementing customary village governance and development within a year, in addition to other noncustomary village-funded activities. As a result, the approved plan must also be transparent, so that all members of the adat village can learn about it and be held accountable. Transparency is a priority for those responsible for administering the Penglatan traditional village fund program, with the goal that the adat village community will respond in order to improve their development performance. Additionally, transparent information is provided throughout the planning and building process.

\subsection{Budgeting}

Prajuru is the embodiment of sekala and niskalabased trust in the budgeting process for customary village funds. By submitting the budget amount provided by the provincial government in the universal planning program, Prajuru provides real (actual) information to village manners present regarding the budget amount and activities carried out. What will be accomplished, where will the funds be spent, and if conventional village manners are invited but not present, they may / are permitted to obtain information directly from the prajuru. However, some of the village customs who were not present were unconcerned, as they already trusted the traditional village prajuru's operations, which they perceived to be transparent in delivering budget information.

The traditional village prajuru's form of community trust in the context of managing village funds was affirmed by the Penglatan Customary Village Bendesa based on the findings of interviews, which claimed that:

“... menyetujui semua kegiatan pengelolaan alokasi dana desa adat dalam acara paruman desa adat, mungkin karena tempat paruman dan sumpah prajuru yang dilakukan itu berlokasi di pura desa, jadi krama sudah menyerahkan pada sekala dan niskala dik".

“... approved all activities for managing the allocation of traditional village funds in the traditional village paroman event, maybe because the location of the prajuru prajuru and the prajuran oath was located at the village temple, so krama has handed it over to sekala and niskala."

According to the theory, trust is the desire of a surrendered party to accept another party's attitude/action based on the expectation that the other party can perform a special action that is critical for the party providing the trust, as well as the other 
party's monitoring and controlling abilities [6] Trust is described as an expectation that arises from honest attitudes and cooperative acts based on shared values and conventions [6].

\subsection{Implementation}

In the 2020 traditional village fund budget, the form of implementing activities in Phase I can be budgeted for a maximum of Rp. 50,000,000 to be used for health care in the Niskala and Sakala Prevention of COVID-19 in the form of: Implementation of the Nunas ica activity which is an abstract activity with Mangku Pura Kahyangan Tiga Nyejer Daksina in Dusun Adat, which began to take place on March 31, 2020 until COVID was over and a follow-up notification appeared, a request to Ida Bhatara Sasuhunan that was adjusted to Drestha Desa Adat Penglatan so that this COVID outbreak would pass quickly so that nature is harmonious, villagers and implementation Sekala's activities, for example, are holding actions to prevent COVID, namely educating and socializing to residents of Indigenous villages and building mutual cooperation among fellow Indigenous Village Krama.

\subsection{Report on Accountability}

The realization of the sekala and niskala-based trust aspects in the accountability stage of managing customary village funds in an accountable manner is that there is a strong sense of trust from village manners toward prajuru, which, in the author's opinion, when viewed in the context of the large budget provided by the Bali Provincial Government, which reaches hundreds of millions of rupiah, in the slightest traditional village prajuru to be tempted or have a plan to. Because the report made it apparent where the monies were going, the assistance offered was spot on. As previously stated, scale and niskala punishments continue to be the primary pillars of financial management. The prajuru's knowledge and understanding of handling traditional village funds are excellent, and the Penglatan Traditional Village prajuru has performed well in carrying out its duties and obligations. This is because krama feels that because sekala and niskala sanctions are highly regarded by the prajuru and the adat village manners, it is certain that the prajuru's many obligations and responsibilities will be carried out effectively.

This is what the Penglatan traditional village manners accomplish; the beneficial experiences of the prajuru in the past, particularly in the management of customary village money, have influenced the beliefs of traditional village manners to this day. The growth of traditional villages that will take place later can achieve the level of contribution made by customary village manners, since they can collectively assist traditional villages in their development success.

\subsection{Aspects of Trust Based on Scale And Niskala in The Practice of Transparency of The Penglatan Traditional Village Fund.}

The openness or transparency of the traditional village institutions is demonstrated by the Penglatan Traditional Village prajuru, who invites the adat village people to participate in paruman or Pesangkepan activities. The Penglatan Traditional Village officers will also communicate significant financial and non-financial matters in a straightforward manner as part of this transparency. Additionally, the traditional village officers will always be forthright and will not hold back when providing information about the management of funds in their village or any other information, because the Penglatan Traditional Village officers are aware that traditional village manners have the right to view the traditional village's financial information. Through the dissemination of this information and the inclusion of traditional village manners in the traditional village village, it is possible to attain programmatic global community empowerment.

This is in accordance with the customary village of Penglatan, which states that anyone who is unable to attend while making a report on the administration of traditional village funds would face sanctions in the form of a fine. As a result, high levels of engagement will result in favorable perceptions of the openness and accountability objectives. Along with fostering a positive perception, krama's active engagement in the transparent process of administering customary village money will help prajuru's financial accountability aims. As an excerpt from a conversation with Ibu Jempiring, who represents the Penglatan traditional village manners:

\section{"Sebelum paruman dilaksanakan beberapa hari sebelumnya sudah ada beberapa prajuru yang turun ke masyarakat memberikan informasi kapan akan ada paruman itu dilaksanakan, jadi paruman dilaksanakan apabila yang datang lebih banyak daripada yang tidak hadir. Jika ada krama yang tidak hadir dengan alasan berhalangan maka akan dikenakan denda yang biasa disebut bakatan (pungutan denda) istilah bahasa balinya dik."}

"Before the paruman was held a few days earlier, there were already several prajuru who came down to the community to provide 
information on when the paruman would be held, so the paroman was carried out if there were more people who came than those who did not attend. If there is a krama who is not present on the grounds of being unable to attend, a fine will be imposed, which is usually called Talentan (fine fee) in Balinese."

This is also supported by the findings when interviewing the Traditional Village Treasurer, he stated that:

\section{"Pada saat paruman, krama akan menerima segala bentuk laporan pertanggungjawanban yang sudah disampaikan karena kita sudah melakukan pertanggungjawaban secara transparan." \\ "At the time of Paruman, krama will receive all forms of accountability reports that have been submitted because we have carried out our accountability transparently."}

[7] trust is a readiness to accept risks in social connections based on the assumption that other individuals can and will always act in a way that benefits the group or themselves. Giving mutual trust in society enables the community to create bonds with one another and contributes to the growth of social capital.

Trust develops when a group shares values or when shared ideals underpin life in order to establish honesty and general expectations. The confidence that develops and strengthens in the customs of the traditional village of Penglatan is a result of the traditional village prajuru's shared values. This is consistent with the Treasurer of the Penglatan Traditional Village's opinion regarding the trust placed in the Penglatan traditional village prajuru to manage customary village funds from planning to implementation, always placing complete trust in the traditional village prajuru, as traditional village manners believe in the existence of karma phala.

“.....jadi kita dalam prajuru desa adat sebelum melaksanakan tugas kita diambil sumpah terlebih dahulu, dan krama desa kembali lagi selalu melibatkan sekala niskala pada semua proses yang kita kerjakan. Jadi masyarakat full memberikan kepercayaanya dan kita akan pertanggungjawab menjalankan tugas apa yang sudah diberikan kepada kita."

"“،...... So we in the traditional village prajuru before carrying out our duties we take an oath first, and the village manners come back again always involve niskala in all the processes we do. So the full community gives their trust and we will be responsible for carrying out the tasks that have been given to us."

This was also supported by the activity of interviewing one of the traditional Penglatan villages, his statement was:

“...... sejak jaman dulu mungkin sebelum ibu mengerti, memang sudah seperti itu, kita sudah percaya pada prajuru yang melaksanakan tugasnya dik. Pertama sebelum mereka melakukan tugas sudah diambil sumpah, terus dari perencanaan sampai kegiatan dan pertanggujawaban pun dilaksanakan ditempat suci biasanya di Pura Bukit Kencana Mas atau Pura Desa. Sebelum melaksanakan kegiatan juga sudah ada persembahyangan, jadi desa adat selalu melibatkan sekala niskala dalam berkegiatan apapun dik. Dan mungkin bila ada yang melakukan kecurangan yang tidak terlihat kita krama yang beragama hindu percaya akan adanya Karma Phala dik."

‘،...... since ancient times maybe before mother understood, it's like that, we already believe in soldiers who carry out their duties, brother. First, before they carry out their duties, they have taken an oath, from planning to activities and accountability are carried out in holy places, usually at Pura Bukit Kencana Mas or Pura Desa. Before carrying out the activity, there was also a prayer, so the traditional village always involved the niskala in any activities, brother. And maybe if someone commits an unseen fraud, we Hindus believe in Karma Phala."

Additionally, he stated that during Paruman, a representative of one of the Prajuru conveyed the results of the accountability, typically the secretary (prajuru Desa adat), and that during the delivery, Krama was also given leaflets outlining the results of the recapitulation of the management of customary village funds.

"Memang tidak semuanya yang mendapatkan selebaran itu karena krama nya yang lumayan banyak dik, disebarkan beberapa lembaran saja nanti itu akan saling bergiliran membacanya dik, jadi saling bagi"

"Indeed, not all of them got the leaflets because of their quite a lot of manners, only a few sheets were distributed and they would take turns reading it, brother, so share it with each other."

According to the author's assumption, the summary of the management of customary village 
funds is also presented in the form of a basic financial report that is easily understood by the general public. According to one of the adat village krama, it was not critical to understand budget management in the Penglatan traditional village and to utilize the spiritual notions they understood to defend their actions.

\section{CONCLUSION}

This means that numerous conclusions can be expressed using ideas and prior study findings, specifically as follows: With the accomplishment of the scale-based and niskala-based dimensions of trust in the accountability of the Penglatan Traditional Village fund management, it is possible to assert that the discoveries obtained via each program and activity can be physically accounted for. Meanwhile, administrative adjustments are required/need to be addressed in order to perfect the applied accountability idea. The principle of accountability, which is applied in phases, can later serve as a foundation for confidence in traditional village manners.

Based on the researcher's results and the constraints of the research outlined in the preceding chapter, the following recommendations or suggestions can be made: The problem of managing traditional village funds in Penglatan Village is excellent; the response of customary village manners is also excellent; however, there needs to be a reapproach to the adat desa krama, so that the accountability report can be quickly received, not just with the word "agree."

To enable the subsequent researcher to locate additional resource persons, specifically the adat village officers, during data collection via interviewing activities in order to provide a more accurate assessment of the adat village officers' responsibilities when handling the Dusun Adat money.

\section{REFERENCES}

[1] A. T. Atmadja, "Penyertaan Modal Sosial dalam Struktur Pengendalian Internal Lembaga Perkreditan Desa," Universitas Airlangga, 2006.

[2] F. Fukuyama, "Trust Kebijakan Sosial Dan Penciptaan Kemakmuran.” 2010.

[3] Sugiyono, Metode Penelitian Kombinasi (Mix Methoders). Alfabeta, 2013.

[4] Peraturan Gubernur Bali, Peraturan Gubernur Bali Nomor 34 Tahun 2019 tentang Pengelolaan Keuangan Desa Adat. 2019.

[5] D. F. Arifiyanto, "Akuntabilitas Pengelolaan Alokasi Dana Desa Di Kabupaten Jember," J. Ris. Akunt. dan Keuang., vol. 2 (3), 2014.

[6] A. Ojha and M. P. Gupta, "Does Egovernment Enhance trust ingovernment.," $J$ Comput. Soc. india, 1998, doi: https://wenku.baidu.com/view/09204ff8770b f78a65295402.html?re=view.

[7] M. F. Ikhwandha, "Pengaruh Transparansi, Akuntabilitas, Kepercayaan Afektif Dan Kognitif Terhadap Minat Bayar Zakat Melalui Lembaga Zakat," UII Yogyakarta, 2018 . 